(July 2020) were included. Medical records were reviewed to collect demographic, clinical and lab test data, using Brescia-COVID respiratory severity scale, SaFi, CRP, Ferritin, LDH and lymphocytes. Variables were assessed at baseline, $72 \mathrm{~h}$ and 7 days after treatment initiation. Descriptive statistical analysis was performed, including a sub-analysis of patients who received anakinra as the only biological treatment.

Results: 54 patients were included, of which 37 male $(68.5 \%)$ with a median age of 69.5 years (36-94). Comorbidities were lung disease 14 pts $(25.9 \%)$, cardiovascular disease 39 pts (72.2\%), Diabetes Mellitus 11 pts (20.4\%), kidney disease and rheumatic disease each in 6 pts (11.1\%), and immunosuppression 13 pts (24.1\%). Each patient received a mean of 4.85 doses of anakinra $( \pm 3.96)$. Other therapies included low-dose steroids (70.3\%); high-dose steroids: $1 \mathrm{mg} / \mathrm{kg}(87 \%)$, bolus (24\%), Tocilizumab (57.4\%), Infliximab (24.1\%), Lopinavir/Ritonavir (48\%), Hydroxychloroquine (94.4\%), and Azithromycin (79.6\%). Mortality was $22 \%$ overall, $75 \%$ due to COVID19, $8.3 \%$ due to infectious complications and $16.7 \%$ due to non-infectious complications. In the group receiving Anakinra as only biological drug, mortality accounted for $17.9 \%$ of patients, $75 \%$ due to COVID19 and $25 \%$ to non-infectious complications. No adverse effects related to anakinra were observed.

\begin{tabular}{|c|c|c|c|c|c|c|c|}
\hline & \multicolumn{3}{|c|}{ General group $(n=54)$} & \multicolumn{3}{|c|}{$\begin{array}{l}\text { Group receiving anakinra as only } \\
\text { biological drug }(n=23)\end{array}$} & \multirow[t]{2}{*}{$\mathbf{P}$} \\
\hline & Baseline & After $72 \mathrm{~h}$ & After $7 d$ & Baseline & After $72 \mathrm{~h}$ & After 7d & \\
\hline Brescia-COVID & $1.65(0.95)$ & $1.63(1.13)$ & $1.73(1.19)$ & $1.09(0.8)$ & $0.91(0.88)$ & $1.09(0.8)$ & \\
\hline Mean(SD) & $\begin{array}{c}\text { Values: } \\
0: 11.1 \% \\
\text { 1: } 31.5 \% \\
2: 42.6 \% \\
3: 53.7 \% \\
4: 3.7 \%\end{array}$ & $\begin{array}{c}\text { Values: } \\
\text { 0: } 16.7 \% \\
\text { 1: } 27.8 \% \\
2: 38.9 \% \\
3: 7.4 \% \\
4: 9.3 \%\end{array}$ & $\begin{array}{c}\text { Values: } \\
0: 7.9 \% \\
1: 52.6 \% \\
2: 18.4 \% \\
3: 7.9 \% \\
4: 13.2 \%\end{array}$ & $\begin{array}{c}\text { Values: } \\
0: 26.1 \% \\
1: 47.8 \% \\
2: 21.7 \% \\
3: 4.34 \% \\
4: 0 \%\end{array}$ & $\begin{array}{c}\text { Values: } \\
0: 39.1 \% \\
1: 34.8 \% \\
2: 21.7 \% \\
3: 4.34 \% \\
4: 0 \%\end{array}$ & $\begin{array}{c}\text { Values: } \\
0: 8.7 \% \\
1: 82.6 \% \\
2: 8.7 \% \\
3: 0 \% \\
4: 0 \%\end{array}$ & NS \\
\hline SaFi & $\begin{array}{c}222.60 \\
(115.2)\end{array}$ & $\begin{array}{c}240.51 \\
(117.6)\end{array}$ & $\begin{array}{c}250.95 \\
(102.6)\end{array}$ & $\begin{array}{c}306.35 \\
(124.7)\end{array}$ & $\begin{array}{c}316.04 \\
(129.8)\end{array}$ & $\begin{array}{c}300.36 \\
(135.4)\end{array}$ & NS \\
\hline Mean (SD) & $\begin{array}{c}\text { Values: } \\
>300: \\
25.9 \% \\
201-299 \\
: 14.8 \% \\
<201: \\
59.3 \%\end{array}$ & $\begin{array}{c}\text { Values: } \\
\text { >300: } \\
24.5 \% \\
201-299 \text { : } \\
26.4 \% \\
<201: \\
49 \%\end{array}$ & $\begin{array}{c}\text { Values: } \\
\text { >300: } \\
34.2 \% \\
201-299 \text { : } \\
34.2 \% \\
<201: \\
31.6 \%\end{array}$ & $\begin{array}{c}\text { Values: } \\
>300 \text { : } \\
56,52 \% \\
201-299: \\
17.39 \% \\
<201: \\
26.1 \%\end{array}$ & $\begin{array}{c}\text { Values: } \\
>300: \\
52.2 \% \\
201-299 \text { : } \\
21.7 \% \\
<201: \\
26.1 \%\end{array}$ & $\begin{array}{c}\text { Values: } \\
>300 \text { : } \\
45.46 \% \\
201-299: \\
27.27 \% \\
<201: \\
27.27 \%\end{array}$ & \\
\hline $\begin{array}{l}\text { Lymphocytes, } \\
10^{\wedge} 3 / \text { microL } \\
\text { Mean (SD) }\end{array}$ & $\begin{array}{l}1.07 \\
(1.5)\end{array}$ & $\begin{array}{c}5.16 \\
(3.05)\end{array}$ & $\begin{array}{c}1.15 \\
(2.49)\end{array}$ & $\begin{array}{c}0.88 \\
(0.56)\end{array}$ & $\begin{array}{c}1.25 \\
(0.79)\end{array}$ & $\begin{array}{l}1.15 . \\
(2.4)\end{array}$ & NS \\
\hline $\begin{array}{l}\text { Ferritine, } \\
\mathrm{ng} / \mathrm{ml} \\
\text { Mean (SD) }\end{array}$ & $\begin{array}{l}1098.4 \\
(944.8)\end{array}$ & $\begin{array}{l}1080.23 \\
(873.9)\end{array}$ & $\begin{array}{l}1069.19 \\
(989.42)\end{array}$ & $\begin{array}{l}1112.76 \\
(621.80)\end{array}$ & $\begin{array}{c}903.25 \\
(385.49)\end{array}$ & $\begin{array}{c}704.14 \\
(261.86)\end{array}$ & NS \\
\hline $\begin{array}{l}\text { C-reactive } \\
\text { protein, } \\
\text { mg/L }\end{array}$ & $\begin{array}{c}38.78 \\
(37.58)\end{array}$ & $\begin{array}{l}21.46 \\
(20.17)\end{array}$ & $7(6)$ & $\begin{array}{c}50 \\
(6.38)\end{array}$ & $\begin{array}{l}34.67 \\
(23.3)\end{array}$ & $\begin{array}{c}19.96 \\
(28.92)\end{array}$ & NS \\
\hline Mean (SD) & & & & & & & \\
\hline $\begin{array}{l}\text { LDH, U/L } \\
\text { Mean (SD) }\end{array}$ & $\begin{array}{l}387.64 \\
(163.1)\end{array}$ & $\begin{array}{c}394.98 \\
(209.32)\end{array}$ & $\begin{array}{c}374.26 \\
(157.63)\end{array}$ & $\begin{array}{l}326.38 \\
(111.66)\end{array}$ & $\begin{array}{c}308 \\
(116.59)\end{array}$ & $\begin{array}{c}355 \\
(151.96)\end{array}$ & NS \\
\hline $\begin{array}{l}\text { Respiratory } \\
\text { improvement* }\end{array}$ & N/A & $20.37 \%$ & $51.85 \%$ & N/A & $30.43 \%$ & $69.5 \%$ & .007 \\
\hline $\begin{array}{l}\text { Lab test } \\
\quad \text { improve- } \\
\text { ment }^{\star \star}\end{array}$ & N/A & $51.85 \%$ & $77.78 \%$ & N/A & $60.87 \%$ & $78.2 \%$ & NS \\
\hline
\end{tabular}

* SaFi normalised or increased $100 \mathrm{mmHg}$ or more ${ }^{\star \star}$ Improvement of 2 or more analytic variables

Conclusion: Anakinra in severe SARS-CoV-2 infection offers respiratory improvement and partial lab tests improvement. No adverse effects were observed. Acknowledgements: We wish to acknowledge Puerta de Hierro Majadahonda COVID19 task force and all the patients and staff affected by the pandemic. Disclosure of Interests: None declared

DOI: 10.1136/annrheumdis-2021-eular.2590

\section{POS1219 SARS-COV-2 VACCINE HESITANCY AMONG PATIENTS WITH RHEUMATIC AND MUSCULOSKELETAL DISEASES: A MESSAGE FOR RHEUMATOLOGISTS}

R. Priori ${ }^{1,2}$, G. Pellegrino $^{1}$, S. Colafrancesco ${ }^{1}$, C. Alessandri ${ }^{1}, F$. Ceccarelli ${ }^{1}$, M. DI Franco ${ }^{1}$, V. Riccieri ${ }^{1}$, R. Scrivo ${ }^{1}$, A. Sili Scavalli ${ }^{1}$, F. R. Spinelli ${ }^{1}$, F. Conti ${ }^{1}$. 'Sapienza University of Rome, Department of Clinical Internal, Anesthesiological and Cardiovascular Sciences, Rome, Italy; ${ }^{2}$ Saint Camillus International University of Health Sciences, Saint Camillus International University of Health Sciences, Rome, Italy

Background: Conflicting results have been published regarding the risk of infection with SARS-CoV-2 and development of severe COVID-19 among patients affected by rheumatic musculoskeletal diseases (RMDs). [1-4] Taking into account the lack of effective drugs to treat the COVID-19 and despite the burdensome and costly lockdown measures adopted to counteract the spread of SARS-CoV-2, effective and safe vaccines appear reasonably to be the best strategy for fighting the virus. [6] Before vaccines availability, several reports showed that a non-negligible proportion of subjects, among the general population or within specific categories, would have refused vaccination against COVID-19 once possible; $[6,7]$ data on vaccination hesitation among patients with RMD are not available yet.

Objectives: This study aimed to evaluate the attitude of patients with RMDs to vaccination against SARS-CoV-2 and explore the factors which may influence it. Methods: During the first weeks of Europe vaccination campaign, we proposed an online survey to Italian adult patients with RMDs followed up in the Rheumatology Unit. All patients fulfilled the most recent classification criteria for each disease. HCs were recruited using a "best friend" system. The informed consent was collected for all participants. The questionnaires included the following items: demographic features, presence of comorbidities, educational level, and ongoing therapy. The individual's perception of the COVID-19 vaccination, as well as the willingness to receive a COVID-19 vaccination with targeted questions was properly assessed. For the statistical analyses, Mann-Whitney and Chi-square tests were used. To account for baseline clinical differences among RMD-patients and controls, multivariable logistic regression analysis was used; covariates were selected according to a clinical criterion. The hypothesis that willingness for COVID-19 vaccine varied in specific subgroups of patients was tested using interaction terms at logistic regression analysis. All statistical tests were performed using the RStudio graphical interface and all tests were two-sided with a significance level set at $p<0.05$.

Results: We provided an online survey to 830 adult RMD-patients and 370 healthy controls (HCs). Overall, $626 \mathrm{RMD}$-patients and $345 \mathrm{HCs}$ completed the survey. Patients with RMDs were less willing to receive a COVID-19 vaccination compared to $\mathrm{HCs}$ (Odds Ratio (OR) $0.24,95 \% \mathrm{Cl} 0.17-0.34, \mathrm{p}<0.0001$ ) despite they perceived themselves as at higher risk both to get infected (OR 11.3, 95\% Cl 8 - 15.9, p<0.0001) and develop a severe COVID-19 (OR 11.06, 95\% Cl 7.8 - 15.6, $\mathrm{p}<0.0001)$ and even if they had been vaccinated for influenza and pneumococcus more frequently than controls $(\mathrm{OR} 1.6095 \% \mathrm{Cl} 1.18-2.16, \mathrm{p}=0.002 ; \mathrm{OR} 2.23,95 \%$ $\mathrm{Cl} 1.34-3.73, \mathrm{p}=0.002$ ). However, our results reveal that RMD-patients are more willing to change their minds if properly informed by the rheumatologist (OR 3.08 , $95 \% \mathrm{Cl} 2.19-4.34, \mathrm{p}<0.0001$ ) in comparison to controls.

Conclusion: The results of our study indicate for the first time that patients with RMDs are less willing to receive COVID-19 vaccination compared to the general population, despite perceiving themselves as at higher risk of getting infected with SARS-CoV-2 and develop severe COVID-19. However, our data underscored a meaningful aspect: patients with RMDs may change their attitude to COVID-19 vaccination if properly informed about risks and benefits by their trusted specialist.

The results of this study encourage the entire rheumatologist community to become more committed to patient education, increasing their willingness to COVID-19 vaccine, which is the most promising strategy to protect them from the virus.

References: 1]Favalli EG et al. Arthritis Rheumatol, 2020

[2] Fredi M, et al. Lancet Rheumatol, 2020

[3] Giardina F et al. Rheumatol Int 2021

[4] Pellegrino G et al. Clin Rheumatol 2020.

[5] Frederiksen LSF, et al. Front Immunol, 2020.

[6] La Vecchia C et al. Med Lav 2020.

[7] Qiao S, et al. medRxiv 2020.

Disclosure of Interests: None declared

DOI: 10.1136/annrheumdis-2021-eular.2622

\section{POS1220 \\ PREGNANT AND POSTPARTUM WOMEN WITH AUTOIMMUNE RHEUMATIC DISEASES AND COVID-19: A CASE SERIES}

R. A. Rodriguez Chavez ${ }^{1}$, C. M. Skinner Taylor ${ }^{1}$, L. Pérez Barbosa ${ }^{1}$, G. Figueroa-Parra', J. E. Compeán-Villegas'1, L. G. Espinosa Banuelos ${ }^{1}$, R. Moyeda Martinez ${ }^{1}$, A. Y. Lujano Negrete ${ }^{1}$, A. Cárdenas ${ }^{1}$, D. Á. GalarzaDelgado'. ${ }^{1}$ Hospital Universitario Dr. José Eleuterio González, Rheumatology Service, Monterrey, Mexico

Background: Pregnant women represent a high-risk population during the COVID-19 pandemic. The main cause of maternal deaths in Mexico during 2020 was COVID-19 with 191 (21.2\%) deaths registered until December 2020. The age group most affected was 30 to 34 years. Women during their third trimester and during puerperium were the most affected. Information regarding pregnant and postpartum women with autoimmune rheumatic diseases remains scarce.

Objectives: The aim of this study was to describe a COVID-19 case series from a clinic of pregnancy and rheumatic diseases.

Methods: We conducted a descriptive, retrospective study in patients from the clinic of pregnancy and rheumatic diseases of the University Hospital "Dr. Jose Eleuterio Gonzalez" in Monterrey, Mexico. Pregnant patients with RD and documented COVID-19 between March and November 2020 were included. Demographic and clinical features were obtained. Results are shown in descriptive statistics. 